\begin{tabular}{|l|l|l||}
\hline \multicolumn{2}{|c|}{ PublisherInfo } \\
\hline \hline PublisherName & $:$ & BioMed Central \\
\hline \hline PublisherLocation & $:$ & London \\
\hline \hline PublisherImprintName & $:$ & BioMed Central \\
\hline \hline
\end{tabular}

\title{
Ventilator acquired pneumonia
}

\begin{tabular}{|l|c|l||}
\hline \multicolumn{2}{|c||}{ ArticleInfo } \\
\hline \hline ArticleID & $:$ & 4188 \\
\hline \hline ArticleDOI & $:$ & $10.1186 /$ ccf-2000-4392 \\
\hline \hline ArticleCitationID & $:$ & 4392 \\
\hline \hline ArticleSequenceNumber & $:$ & 47 \\
\hline \hline ArticleCategory & $:$ & Paper Report \\
\hline \hline ArticleFirstPage & $:$ & 1 \\
\hline \hline ArticleLastPage & $:$ & 2 \\
\hline \hline & & RegistrationDate : 2000-2-24 \\
\hline ArticleHistory & $:$ & OnlineDate \\
\hline \hline ArticleCopyright & $:$ & Current Science Ltd2000-24 \\
\hline \hline ArticleGrants & $:$ & \\
\hline \hline ArticleContext & $:$ & 1305422 \\
\hline \hline
\end{tabular}




\section{Adrian Steele}

\section{Keywords}

Antibiotic therapy, core antibiotics, hospital acquired pneumonia, nosocomial pneumonia

\section{Comments}

This is an interesting and comprehensive review of nosocomial pneumonia in the intensive care unit. Risk factors, including supine position (head of bed $<30^{\circ}$ ) are listed, as are the common pathogens. The importance and difficulty of differentiating between colonisation and parenchymal infection are emphasised. There is an interesting review of the role of invasive procedures (e.g. broncho-alveolar lavage) in diagnosis. A highly complicated treatment flowchart based on American Thoracic Society guidelines is also presented. While the principles are sound, most readers will probably find this no substitute for a combination of clinical judgement and good microbiological advice, based on local knowledge. Finally, the discussion of "crop rotation" or scheduled changes in selection of empiric therapy, as a method of reducing the rate of ventilator acquired pneumonia, interested me.

\section{References}

1. Yeghiazarians Y, Braustein JB, Askari A, Stone PH: Nosocomial pneumonia: intensive care unit perspective. Curr Treat Opt Infect Dis. 2000, 1: 159-175.

This PDF file was created after publication. 